\title{
Iron oxide/titania composites for radar absorbing material (RAM) applications
}

\section{(Compósitos de óxido de ferro/titânia para aplicações como material absorvedor de radar - RAM)}

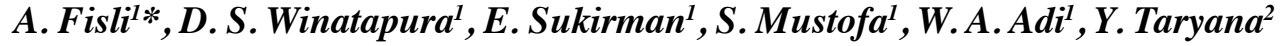 \\ ${ }^{I}$ National Nuclear Energy Agency, Center for Science and Technology of Advanced Materials, \\ Gd. 42 Kawasan Puspiptek Serpong, Tangerang Selatan, Banten, Indonesia \\ ${ }^{2}$ Indonesian Institute of Sciences, Research Center for Electronic and Telecommunication, Bandung, Indonesia
}

\begin{abstract}
Iron oxide/titania composites were synthesized by precipitation method. Amount of iron oxide was varied in the composites. The single phase (anatase) was obtained for the weight ratio of 0-20\% and three phases (anatase, magnetite and hematite) were found for the weight ratio of $30 \%$ and $40 \%$ of iron oxide. The crystallite size of titania decreased with increasing of iron oxide content. The specific surface area, total pore volume and BJH pore volume of the sample increased with increasing iron oxide content in the composite. The composites possessed mesoporous characteristic (6.5-9.6 $\mathrm{nm}$ in pore diameter) and exhibited ferromagnetic properties. The measurement of the microwave absorption showed that the $40 \mathrm{Fe} / \mathrm{Ti}$ composite had the best reflection loss of $-14 \mathrm{~dB}$ at a frequency of $10.9 \mathrm{GHz}$. This meant that the electromagnetic wave was absorbed $80 \%$ in that frequency. Thus, the developed material can be a promising microwave absorbing agent in radar signature reduction.
\end{abstract}

Keywords: radar absorbing materials (RAM), iron oxide, titania, magnetic, dielectric.

\section{Resumo}

Compósitos de óxido de ferro/titânia foram sintetizados pelo método de precipitação. A quantidade de óxido de ferro foi variada nos compósitos. Fase única (anatásio) foi obtida para a fração em massa de 0-20\% e três fases (anatásio, magnetita e hematita) foram encontradas para as frações de $30 \%$ e $40 \%$ de óxido de ferro. $O$ tamanho de cristalito da titânia diminuiu com o aumento do teor de óxido de ferro. A área superficial específica, o volume total de poros e o volume de poros BJH da amostra aumentaram com o aumento do teor de óxido de ferro no compósito. Os compósitos possuíram características mesoporosas (6,5-9,6 $\mathrm{nm}$ de diâmetro de poro) e exibiram propriedades ferromagnéticas. A medição da absorção de micro-ondas mostrou que o compósito $40 \mathrm{Fe}$ /Ti teve a melhor perda por reflexão de - $14 \mathrm{~dB}$ na frequência de 10,9 GHz. Isso significou que a onda eletromagnética foi absorvida em $80 \%$ nessa frequência. Assim, o material desenvolvido pode ser um promissor agente absorvedor de micro-ondas na redução de assinatura radar.

Palavras-chave: materiais absorvedores de radar (RAM), óxido de ferro, titânia, magnético, dielétrico.

\section{INTRODUCTION}

Radar absorbing material (RAM) is signed by the transformation of electromagnetic wave energy into thermal energy to reduce the electromagnetic wave reflection [1]. It was used widely in military applications (reduction of radar signature of aircraft, ships, tanks, and targets) as well as in civilian applications (reduction of electromagnetic interference among components and circuits, reduction of the back-radiation of microstrip radiators) [2]. The excellent

* (D) https://orcid.org/0000-0003-4378-4944 radar absorbing material (RAM) should have certain properties as follows: 1) exhibit strong microwave absorption properties over a wide frequency range; 2 ) need to be thin and lightweight (especially for aircraft); 3) have a simple coatinglayer structure and spend less working time during the urgent process [1]. However, the existing conventional radar absorbing materials have several disadvantages, namely, high density, low environmental stability, narrow effective absorption bandwidth, and weak absorption capacity, so its future application is very limited to fulfill various requirement [3]. Interaction of electromagnetic radiation with a material can occur through dielectric loss and magnetic loss [4]. Dielectric materials can absorb microwave energy 
and convert it to heat via the rotation of polar molecules at high frequencies and the ion-drag at low frequencies [5]. $\mathrm{TiO}_{2}$ (titanium oxide) is an important semiconductor which has environmentally and thermally stable dielectric properties with high relative dielectric constant [6], so it can potentially be used as a microwave absorber [7]. Previous literature mentions that titanium thin film shows microwave attenuation value around 50\% in broadband $(8-12 \mathrm{GHz})$ [8]. Kumar et al. [4] reported that the $\mathrm{Al}$ metal dispersed $\mathrm{TiO}_{2}$ has obtained the maximum absorption with reflection loss (RL) value of $-13.67 \mathrm{~dB}$ at $10.13 \mathrm{GHz}$ and $-7.24 \mathrm{~dB}$ at 10.38 $\mathrm{GHz}$ for $\mathrm{Ni}$ dispersion. The composite $\mathrm{TiO}_{2} /$ chlorinated polyethylene (CPE) can absorb the electromagnetic (EM) wave in W-band radio frequencies; the one containing $70 \%$ $\mathrm{TiO}_{2}$ has a maximum absorption value of $30 \mathrm{~dB}$ at $87 \mathrm{GHz}$ and $29 \mathrm{~dB}$ at $92 \mathrm{GHz}$ [9].

Dielectrics usually have small permeability, and the most magnetic materials have small permittivity. The material with magnetic losses interacts with the magnetic wave field. The magnetic loss is caused mainly by natural resonance, which is in good agreement with the Kittel equation results. Various magnetic materials have been used to absorb electromagnetic wave, but they are limited to three types, such as hexaferrites, spinel ferrites and garnet $[3,10] . \mathrm{Fe}_{3} \mathrm{O}_{4}$ has attractive physical properties, namely, superparamagnetism, high coercivity, low Curie temperature, high magnetic susceptibility, strong spin polarization, etc. $\mathrm{Fe}_{3} \mathrm{O}_{4}$ nanoparticles have been mentioned as the attenuator of the electromagnetic wave. The $30 \%$ volume fraction of magnetite $\left(\mathrm{Fe}_{3} \mathrm{O}_{4}\right)$ in paraffin wax reached the maximum RL value of $-21.2 \mathrm{~dB}$ at $8.16 \mathrm{GHz}$ in $3 \mathrm{~mm}$ thickness [11]. Combined electric-magnetic materials offer the best potential for thin broadband absorption [5]. The composite containing both dielectric and magnetic components is also wellconsidered in the field of electromagnetic interference (EMI) shielding and radar absorbing material [12]. Guan et al. [13] reported that $\mathrm{Fe}_{3} \mathrm{O}_{4}$ /graphene nanocomposite exhibits both enhanced dielectric and magnetic losses at 2-18 GHz. The microwave absorption of $\mathrm{MnFe}_{2} \mathrm{O}_{4}-\mathrm{TiO}_{2}$ nanocomposites was higher than the $\mathrm{MnFe}_{2} \mathrm{O}_{4}$. Zhu et al. [14] reported that $\mathrm{Fe}_{3} \mathrm{O}_{4} / \mathrm{TiO}_{2}$ core/shell nanotubes for electromagnetic wave absorption were fabricated through a three-step process, such as hydrothermal method, a wet-chemical method, and calcination process under a mixture of $\mathrm{Ar} / \mathrm{H}_{2}$ flow. The maximum reflection loss of the material reaches $-20.6 \mathrm{~dB}$ at 17.28 GHz for the absorber with a thickness of $5 \mathrm{~mm}$. Both spinel ferrite/ $\mathrm{SrTiO}_{3}$ and spinel ferrite $/ \mathrm{SrTiO}_{3} / \mathrm{PANI}$ at $1 \mathrm{~mm}$ thickness have a good-performance absorber with reflection loss value less than $-20 \mathrm{~dB}$ in X-band [3]. The efficiency of electromagnetic wave absorption for flower-like tubular $\mathrm{ZnO} / \mathrm{Fe}_{3} \mathrm{O}_{4}$ increased compared to the pure $\mathrm{ZnO}$ or $\mathrm{Fe}_{3} \mathrm{O}_{4}$ [15]. The particle morphology plays a major role in absorbing behavior. The increase of the specific surface area of particles in the composite possibly contributes to the improvement of microwave absorption property due to achieving a higher percolation threshold [16]. The bowl-like $\mathrm{Fe}_{3} \mathrm{O}_{4}$ hemispheres with a hollow exhibit improved microwave absorbing properties compared with ball-like $\mathrm{Fe}_{3} \mathrm{O}_{4}$ microspheres [17]. Particle size and shape lead to multiple scattering events and result in loss of electromagnetic energy in the form of heat. Defects in material structure, like surface, inhomogeneous distribution of phases and presence of pores, are all main contributors to loss mechanism and in turn to the absorption of the radar wave.

The aim of this paper was to obtain the combined dielectric-magnetic material suitable for use as a microwave absorber in X-band range ( 8 to $12 \mathrm{GHz}$ ). The composite of iron oxide/titania was prepared by precipitation method. In the previous study, we have investigated the effect of calcinations of $\mathrm{Fe}_{3} \mathrm{O}_{4} / \mathrm{TiO}_{2}$ composite for microwave absorption [18]. In this study, the amount of iron oxide in the composite was varied from $0-40 \%$ in weight ratio. The characteristics and microwave absorption properties of the material were investigated by various techniques, so showing promising for X-band application as an effective microwave absorber.

\section{EXPERIMENTAL}

Materials: all chemicals used in the experiment were analytical pro analysis grade, i.e., titanium tetrachloride $\left(\mathrm{TiCl}_{4}\right) 98 \%$, ferric chloride $\left(\mathrm{FeCl}_{3} .6 \mathrm{H}_{2} \mathrm{O}\right)$, ferrous chloride $\left(\mathrm{FeCl}_{2} \cdot 4 \mathrm{H}_{2} \mathrm{O}\right)$, and ammonium hydroxide $\left(\mathrm{NH}_{4} \mathrm{OH}\right)$. All chemicals were purchased from Merck and used without further purification. Deionized water was used in all experiments.

Preparation of Fe/Ti composites: the solution of $0.3 \mathrm{M}$ $\mathrm{TiCl}_{4}$ was prepared by dissolving titanium tetrachloride $\left(\mathrm{TiCl}_{4}\right)$ in distilled water in an ice-water bath. In another container, $5.2 \mathrm{~g}$ of $\mathrm{FeCl}_{3} .6 \mathrm{H}_{2} \mathrm{O}$ and $2.0 \mathrm{~g}$ of $\mathrm{FeCl}_{2}$ were dissolved in $10 \mathrm{~mL} \mathrm{HCl} 1 \mathrm{~N}$ under vigorous stirring and with the addition of $15 \mathrm{~mL}$ of distilled water. This mixture resulted in an aqueous solution with a molar ratio of $\mathrm{Fe}(\mathrm{II}) / \mathrm{Fe}(\mathrm{III})=0.5$, important to produce the magnetic particles. The iron solution was added to the $\mathrm{TiCl}_{4}$ solution under vigorous stirring at room temperature. The resulting solution was added dropwise into $250 \mathrm{~mL}$ of $1.5 \mathrm{NH}_{4} \mathrm{OH}$ solution under vigorous stirring. The formed precipitate was separated from the supernatant by decantation process. Obtained solid was repeatedly washed until the removal of the supernatant. The loading of $\mathrm{Fe}(\mathrm{II}) / \mathrm{Fe}(\mathrm{III})=0.5$ on $\mathrm{TiO}_{2}$ was varied in weight ratio of $0 \%, 10 \%, 20 \%, 30 \%$ and $40 \%$ corresponding to sample code $0 \mathrm{Fe} / \mathrm{Ti}, 10 \mathrm{Fe} / \mathrm{Ti}, 20 \mathrm{Fe} / \mathrm{Ti}$, $30 \mathrm{Fe} / \mathrm{Ti}$ and $40 \mathrm{Fe} / \mathrm{Ti}$, respectively. The obtained solid was dried in an oven at $100^{\circ} \mathrm{C}$ and calcinated in a furnace at $500{ }^{\circ} \mathrm{C}$ under atmosphere condition for $3 \mathrm{~h}$.

Characterization: X-ray diffraction patterns of the samples were recorded with an Empyrean Panalytical with $\mathrm{CuK} \alpha$ radiation, $\lambda=1.154 \AA$, operated at $40 \mathrm{kV}$ and $30 \mathrm{~mA}$ for the $2 \theta$ range $10^{\circ}-80^{\circ}$ with scan step of $0.02^{\circ}$. The calibration of the diffractometer used Si powder. The average crystallite size was determined according to the Debye-Scherrer formula using XRD data. The magnetic properties were measured by vibrating sample magnetometer (VSM-Oxford 
type $1.2 \mathrm{~T}$ ) at room temperature in the applied field rate of 0.25 tesla/min, ranging from -1 to +1 tesla. The morphology of the composite was examined by transmission electron microscopy (TEM, JEM-14000, Jeol). TEM samples were prepared by dispersing the sample in ethanol and dropping the suspension on a copper grid. The chemical bond of oxide was analyzed by a Raman spectrometer (Bruker, s.n. 254) with radiation of $785 \mathrm{~nm}$ and power of $1 \mathrm{~mW}$. $\mathrm{N}_{2}$ adsorption-desorption isotherms were measured in a Quadrasorb SI-4-Kr/MP, Quantachrome Instr., at the liquid nitrogen temperature $(77 \mathrm{~K})$. Before measurement, the samples were degassed at $300{ }^{\circ} \mathrm{C}$ for $3 \mathrm{~h}$. The microwave absorption properties of the composite were measured at room temperature using a microwave vector network analyzer (VNA-Advantest R3770) with a frequency range from 8 to $12 \mathrm{GHz}$.

\section{RESULTS AND DISCUSSION}

$\mathrm{X}$-ray diffraction (XRD) is the most commonly used technique for the study of crystal structure and atomic spacing. The identified XRD patterns of the sample may be used to determine its structure phase, average crystallite size and sample purity. Fig. 1A shows XRD patterns of the sample with different iron oxide contents. On $0 \mathrm{Fe} / \mathrm{Ti}$ curve (pure $\mathrm{TiO}_{2}$ ), it was clearly observed that diffractogram was similar to the standard diffraction pattern of anatase in Match software file No. 96-900-8214. Other titanium oxide polymorph, such as rutile and brookite, was not detected, which indicated the high purity of the product. Likewise, for $10 \mathrm{Fe} / \mathrm{Ti}$ and $20 \mathrm{Fe} / \mathrm{Ti}$, no additional peaks were observed. However, the peaks broadened, indicating that either the particle had a smaller crystallite size, or the particles were semi-crystalline in nature [19]. Especially for both $30 \mathrm{Fe} / \mathrm{Ti}$ and $40 \mathrm{Fe} / \mathrm{Ti}$ curves, extra peaks which were assigned to the hematite and the magnetite appeared. The XRD patterns of $0 \mathrm{Fe} / \mathrm{Ti}, 10 \mathrm{Fe} / \mathrm{Ti}$, and $20 \mathrm{Fe} / \mathrm{Ti}$ were similar which indicated the same (anatase) phase containing samples, meaning that substitution of $\mathrm{Fe}^{2+}$ and $\mathrm{Fe}^{3+}$ ions into $\mathrm{Ti}^{4+}$ ions occurred. Part of the position of $\mathrm{Ti}^{4+}$ ions was occupied by $\mathrm{Fe}^{2+}$ and $\mathrm{Fe}^{3+}$ ions but the content of the substituted $\mathrm{Fe}$ ions in $\mathrm{Ti}^{4+}$ ions was able only up to $20 \%$. Furthermore, if the added Fe ion content was more than $20 \%$, not all the $\mathrm{Fe}^{2+}$ and $\mathrm{Fe}^{3+}$ ions could substitute the position of $\mathrm{Ti}^{4+}$. Excess of $\mathrm{Fe}^{2+}$ and $\mathrm{Fe}^{3+}$ ions (above 20\%) created new phases that were the phases of magnetite and hematite in a $\mathrm{TiO}_{2}$ matrix. This result requires further analysis related to the structure parameter, refinement and the analysis of its cationic distribution which will be discussed in detail in another paper. The crystallite size of the $\mathrm{TiO}_{2}$ particles was determined from the broadening of the major diffraction peak, (101) plane, using the wellknown Scherrer's formula:

$$
\text { Crystallite size }=\frac{0.9 \lambda}{\mathrm{B} \cos \theta}
$$

where $\lambda$ is the X-ray wavelength, $\theta$ the angle of Bragg diffraction, and $\mathrm{B}$ the difference between the full-width at half-maximum (FWHM) of peak and the instrumental broadening correction. The crystallite size of pure $\mathrm{TiO}_{2}(0 \mathrm{Fe} /$ Ti) was about $81.2 \mathrm{~nm}$. The presence of iron oxide on titania decreased the anatase crystallite size drastically $(10.3 \mathrm{~nm}$ for $10 \mathrm{Fe} / \mathrm{Ti}$ ). The increase of iron oxide content gradually decreased the crystallite size of titania (10.2,9.5 and $9.0 \mathrm{~nm}$ for $20 \mathrm{Fe} / \mathrm{Ti}, 30 \mathrm{Fe} / \mathrm{Ti}$ and $40 \mathrm{Fe} / \mathrm{Ti}$, respectively). This result indicated that the dispersed iron oxide on composite retarded the grain growth of $\mathrm{TiO}_{2}$ particles. This result was similar to that in [20] where the crystallite size of $\mathrm{TiO}_{2}$ decreased after doping with $\mathrm{Cu}^{2+}$ or $\mathrm{Zn}^{2+}$.
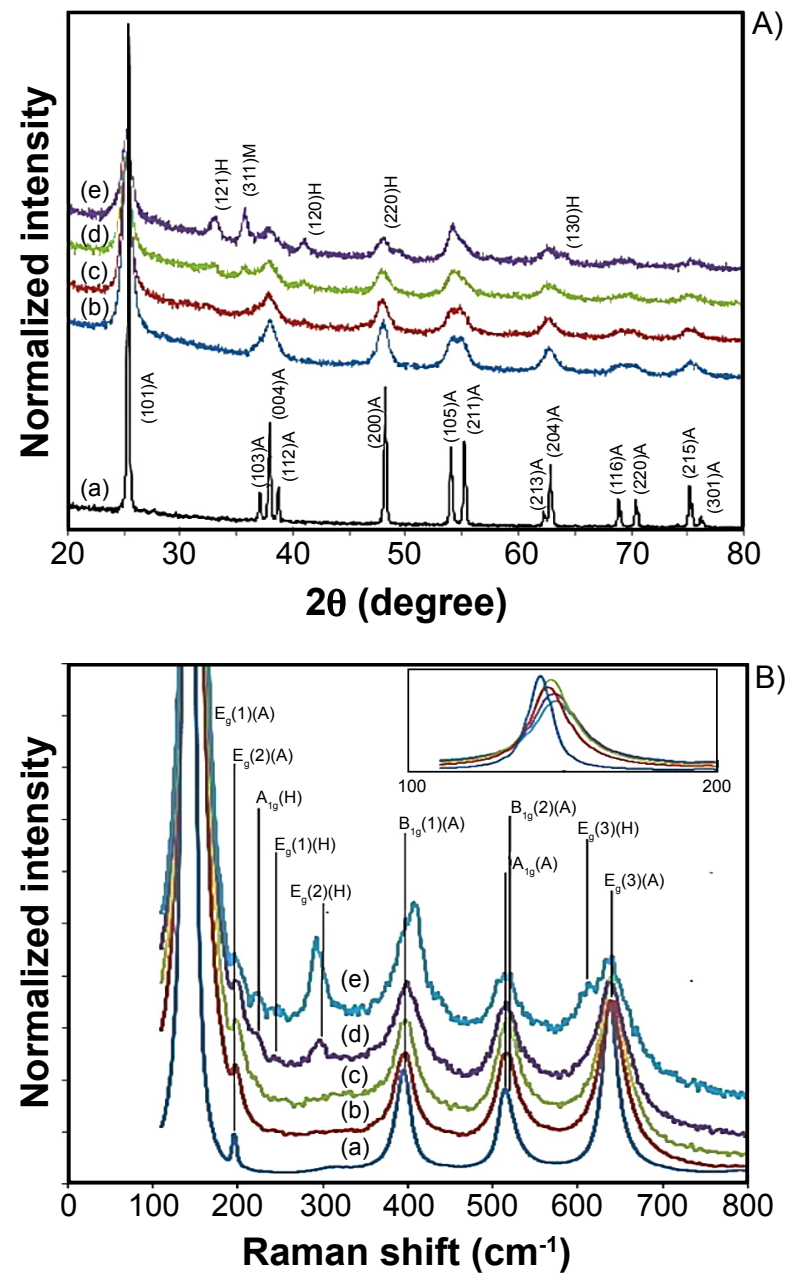

Figure 1: XRD patterns (A) and Raman spectra (B) for the composites: a) $0 \mathrm{Fe} / \mathrm{Ti}$; b) $10 \mathrm{Fe} / \mathrm{Ti}$; c) $20 \mathrm{Fe} / \mathrm{Ti}$; d) $30 \mathrm{Fe} / \mathrm{Ti}$; and e) $40 \mathrm{Fe} / \mathrm{Ti}$. A-anatase $\left(\mathrm{TiO}_{2}\right)$; H-hematite $\left(\mathrm{Fe}_{2} \mathrm{O}_{3}\right)$; M-magnetite $\left(\mathrm{Fe}_{3} \mathrm{O}_{4}\right)$.

[Figura 1: Padrões de DRX (A) e espectros Raman (B) para os compósitos: a) OFe/Ti; b) $10 \mathrm{Fe} / \mathrm{Ti}$; c) $20 \mathrm{Fe} / \mathrm{Ti}$; d) 30Fe/Ti; e e) 40Fe/Ti. A-anatásio $\left(\mathrm{TiO}_{2}\right) ; \mathrm{H}$-hematita $\left(\mathrm{Fe}_{2} \mathrm{O}_{3}\right) ; \mathrm{M}$-magnetita $\left(\mathrm{Fe}_{3} \mathrm{O}_{4}\right)$.]

The Raman spectroscopy is very useful for the identification of $\mathrm{TiO}_{2}$ structure because its spectrum is quite distinct. Group theory predicts six Raman active modes for the tetragonal anatase phase: three $\mathrm{E}_{\mathrm{g}}$ modes centered around 144,197 , and $639 \mathrm{~cm}^{-1}$; two $\mathrm{B}_{1 \mathrm{~g}}$ modes at 399 and $519 \mathrm{~cm}^{-1}$; and one $\mathrm{A}_{1 \mathrm{~g}}$ mode at $513 \mathrm{~cm}^{-1}$ [21]. The Raman bands at 639, 
519 and $399 \mathrm{~cm}^{-1}$ denote $\mathrm{Ti}-\mathrm{O}$ bonding vibration in $\mathrm{TiO}_{6}^{8}$ and at 144 and $197 \mathrm{~cm}^{-1}$ denote Ti-Ti bonding vibration in the octahedral chains [22]. As shown in Fig. 1B, the frequencies of the Raman bands noted for the anatase $\left(\mathrm{TiO}_{2}\right.$ powders with various $\mathrm{Fe} / \mathrm{Ti}, 0$ to $40 \mathrm{wt} \% \mathrm{Fe}$ ) were 142-148, 195-196, 395$399,514-517$ and $638-640 \mathrm{~cm}^{-1}$. As noted, the band at about $146 \mathrm{~cm}^{-1}\left(\mathrm{E}_{\mathrm{g}(1)}\right)$ was the strongest of all the observed bands. The position of $\mathrm{E}_{\mathrm{g}(1)}$ Raman mode for different $\mathrm{TiO}_{2}$ sample ranged between 142 and $148 \mathrm{~cm}^{-1}$, while its linewidth varied from 9.6 to $16.2 \mathrm{~cm}^{-1}$. There are several factors that can contribute to the shift in the peak position, linewidth, and shape of the $\mathrm{E}_{\mathrm{g}(1)}$ Raman mode in anatase $\mathrm{TiO}_{2}$ nanopowder, such as phonon confinement, strain, non-homogeneity of the particle size distribution, defects, non-stoichiometry and anharmonic effect [23]. It is not easy to separate each effect among these various contributions [24]. However, according to the observations, the dominant factor of peak shift in Raman spectra seems to have been determined by the introduction of $\mathrm{Fe}$ ion into the $\mathrm{TiO}_{2}$ lattice and the existence of mixed phases (anatase in combination with iron oxide). Additionally, it was observed that the increasing Fe content on composite induced lower intensities and larger band widths of these vibrational modes. These results indicated more disorder and partial amorphization of anatase in all the samples [23]. In the Raman spectra, it was also observed the new peaks at 226,245 and $292 \mathrm{~cm}^{-1}$ for $30 \mathrm{Fe} / \mathrm{Ti}$ and $40 \mathrm{Fe} / \mathrm{Ti}$ which were ascribed to the hematite phase of iron oxide, but magnetite phase was not detected. The magnetite phase can change into hematite phase due to a temperature increase of several hundred degrees during the use of a strongly focused laser on Raman measurement [25].

Typical TEM images of $40 \% \mathrm{Fe} / \mathrm{Ti}$ are presented in Fig. 2 to show the morphology and size distribution of particles. The particles exhibited a spherical shape. The average particle size matched the XRD result, estimated less than $20 \mathrm{~nm}$, but some agglomeration occurred due to the high surface energy of the nanoparticles. It was clear in TEM images that iron oxide was wrapped around the titania surface, forming a heteroaggregate structure for the iron oxide/titania nanocomposite. In the micrographs of Fig. 2, the black region is the magnetic iron oxide, and the gray area is the titania; these color differences arose because of the difference in electron penetrability.

Physisorption is commonly the technique to study the pore characteristic of solid material. The amount of gas adsorbed on a solid material can be determined accurately which is directly related to its porous properties and structure. Fig. 3 shows the $\mathrm{N}_{2}$ adsorption-desorption isotherms of various composites. According to the IUPAC updating classification of adsorption isotherms published in 2015, the isotherms of all prepared composites were identified as type IV(a) isotherm. This indicated that the obtained samples had a mesoporous structure where capillary condensation is accompanied by hysteresis [26]. The update of hysteresis loop shapes was classified into six types, i.e. H1, H2(a), $\mathrm{H} 2$ (b), H3 and H5. The type H1 hysteresis loop was not chosen due to its predominance under extreme conditions
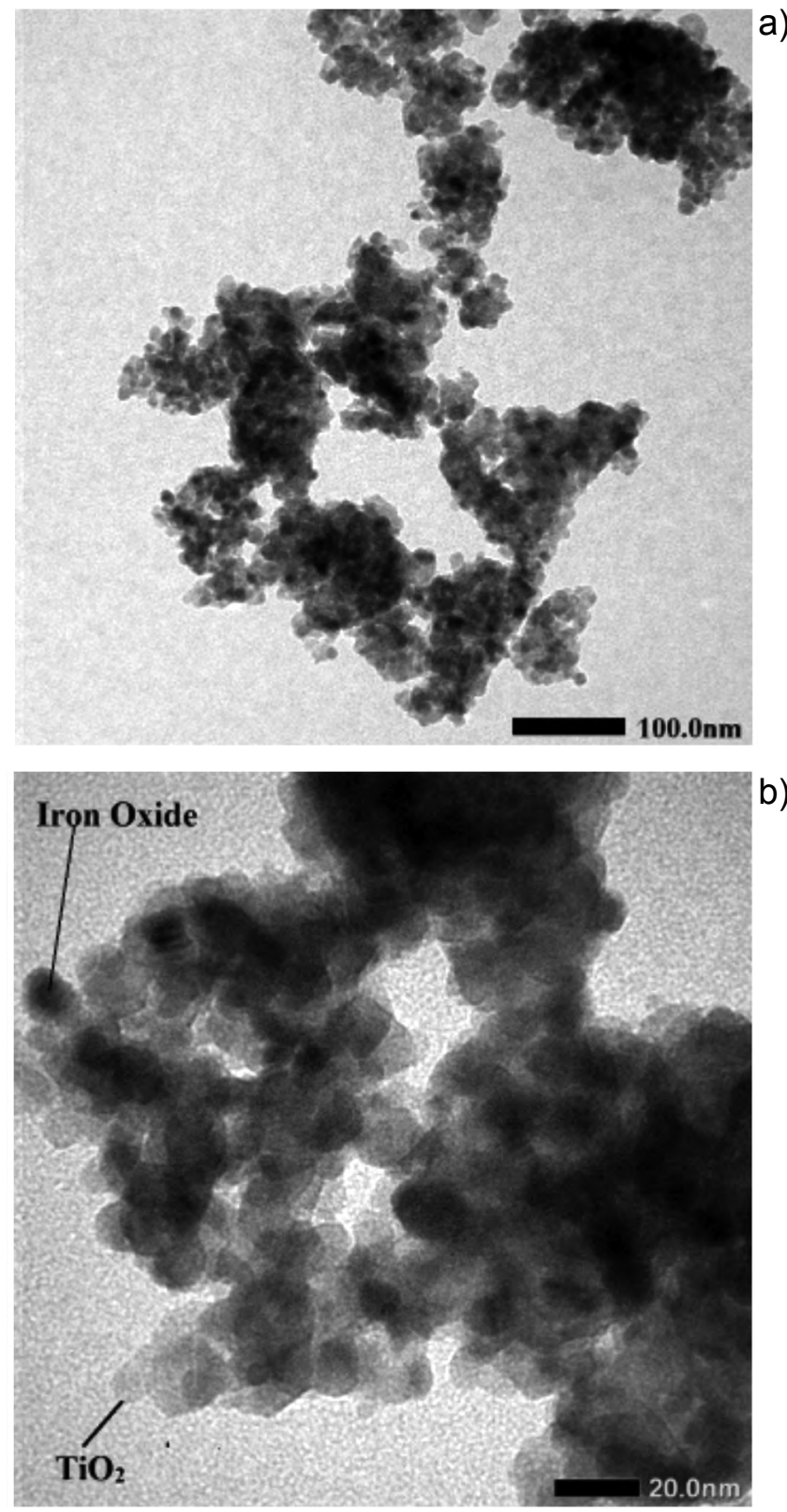

Figure 2: TEM images of the $40 \% \mathrm{Fe} / \mathrm{Ti}$ composite.

[Figura 2: Imagens de MET do compósito 40\% Fe/Ti.]

[27]. It is usually possessed by ordered mesoporous material [26] and/or with a narrow range of uniform mesopores [28]. Type $\mathrm{H} 2$ hysteresis loop is the average condition where the pore characteristic is not well-defined or irregular [27] and has a more complex pore structure with disordered network effects [28]; the desorption branch of the hysteresis loop is less steep. The obtained samples had hysteresis loops fairly closely related to the characteristics of type $\mathrm{H} 2$ (b) which can be attributed to pore blocking and the wider size distribution of neck widths [28].

The specific surface area of the sample was determined by BET (Brunauer-Emmet-Teller) method with P/Po range of 0.05-0.35 to find the monolayer coverage of the surface. Increasing the relative pressure to $0.4-0.8$, with broad hysteresis loops, the capillary condensation within mesopore 


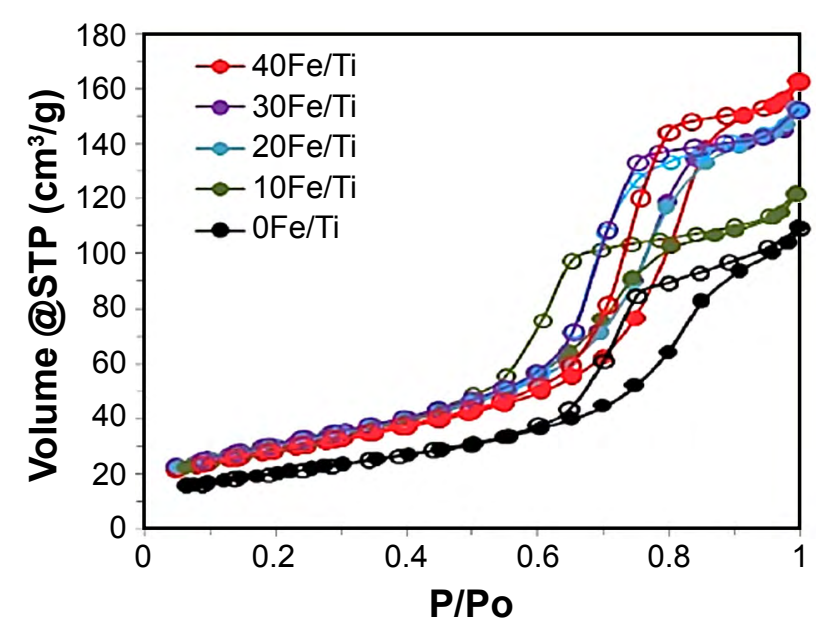

Figure 3: $\mathrm{N}_{2}$ adsorption-desorption isotherms for various composites.

[Figura 3: Isotermas de adsorção-dessorção de $\mathrm{N}_{2}$ para vários compósitos.]

occurred, which was estimated by the BJH (Barett-JoynerHalenda) method [29]. The total pore volume was assessed from the amount of $\mathrm{N}_{2}$ gas adsorbed at a relative pressure $(\mathrm{P} / \mathrm{Po})$ close to 1 which is assumed that the pore is filled with the adsorbate in the bulk liquid state [30]. The specific surface area, total pore volume and BJH pore volume of the prepared samples are compiled in Table I. Specific surface areas of all composites sample were much higher than that of pure $\mathrm{TiO}_{2}$. This fact implied that the substitution of $\mathrm{Fe}^{2+}$ and $\mathrm{Fe}^{3+}$ into $\mathrm{Ti}^{4+}$ ion significantly affected the surface area of $\mathrm{TiO}_{2}$ particles. Surface area data were consistent with the $\mathrm{Fe}^{2+} / \mathrm{Fe}^{3+}$ ion content up to $30 \%$ and after that, there was a difference. However, the total and BJH pore volume of the sample consistently increased with increasing $\mathrm{Fe}^{2+} / \mathrm{Fe}^{3+}$ ion content in all composites. The mesopore volume value was slightly below the total pore volume. It was considered that the obtained composite is dominant in the mesoporous structure.

Table I - Results of specific surface area, total pore volume and BJH pore volume of the prepared samples.

[Tabela I - Resultados de área superficial específica e volumes de poros total e de BJH das amostras preparadas.]

\begin{tabular}{cccc}
\hline Sample & $\begin{array}{c}\text { Surface } \\
\text { area } \\
\left(\mathrm{m}^{2} / \mathrm{g}\right)\end{array}$ & $\begin{array}{c}\text { Total pore } \\
\text { volume } \\
\left(\mathrm{cm}^{3} / \mathrm{g}\right)\end{array}$ & $\begin{array}{c}\text { BJH pore } \\
\text { volume } \\
\left(\mathrm{cm}^{3} / \mathrm{g}\right)\end{array}$ \\
\hline $\mathrm{Pure} \mathrm{TiO}_{2}$ & 70.7 & 0.170 & 0.163 \\
$10 \mathrm{Fe} / \mathrm{Ti}$ & 107.1 & 0.189 & 0.177 \\
$20 \mathrm{Fe} / \mathrm{Ti}$ & 107.5 & 0.237 & 0.231 \\
$30 \mathrm{Fe} / \mathrm{Ti}$ & 109.1 & 0.236 & 0.232 \\
$40 \mathrm{Fe} / \mathrm{Ti}$ & 109.8 & 0.252 & 0.248 \\
\hline
\end{tabular}

The method for pore size distribution calculation from adsorption isotherms has been known for a long time. The simplest calculation methods are based on the BJH model considering the data on both adsorption and desorption branch isotherms [31]. Fig. 4 shows the pore size distribution of the various prepared samples, calculated according to the $\mathrm{BJH}$ method. It was observed that all the prepared samples had not uniform pore size distribution with a wide range around $3-11 \mathrm{~nm}$ in pore diameter. The average pore size of the sample was $9.5,6.5,9.4,9.4$ and $9.6 \mathrm{~nm}$ for $0 \mathrm{Fe} / \mathrm{Ti}, 10 \mathrm{Fe} / \mathrm{Ti}, 20 \mathrm{Fe} / \mathrm{Ti}, 30 \mathrm{Fe} / \mathrm{Ti}$ and $40 \mathrm{Fe} /$ $\mathrm{Ti}$, respectively. According to IUPAC recommendation, pore type can be classified according to its size, such as micropore $(\mathrm{d}<2 \mathrm{~nm})$, mesopore $(2<\mathrm{d}<50 \mathrm{~nm})$ and macropore $(\mathrm{d}>50 \mathrm{~nm}$, where $\mathrm{d}$ is the pore diameter) [32] Thus, all prepared samples were included as mesoporous material. Pore in solid is classified into the interparticle pore and intraparticle pore. Interparticle pore was formed as a result of the agglomeration or aggregation of particles. The intraparticle pore can be divided into intrinsic intraparticle pore which arises from the intrinsic crystalline structure and extrinsic intraparticle pore where a foreign substance is impregnated in parent material during the particle growth advance [33]. The addition of $\mathrm{Fe}^{3+} / \mathrm{Fe}^{2+}$ ion into $\mathrm{TiO}_{2}$ tended to form intrinsic intraparticle pore up to $20 \mathrm{Fe} /$ $\mathrm{Ti}$ and after that tended to form an extrinsic intraparticle pore. This result was in line with previous XRD results where the new phases appeared for $30 \mathrm{Fe} / \mathrm{Ti}$ and $40 \mathrm{Fe} / \mathrm{Ti}$.

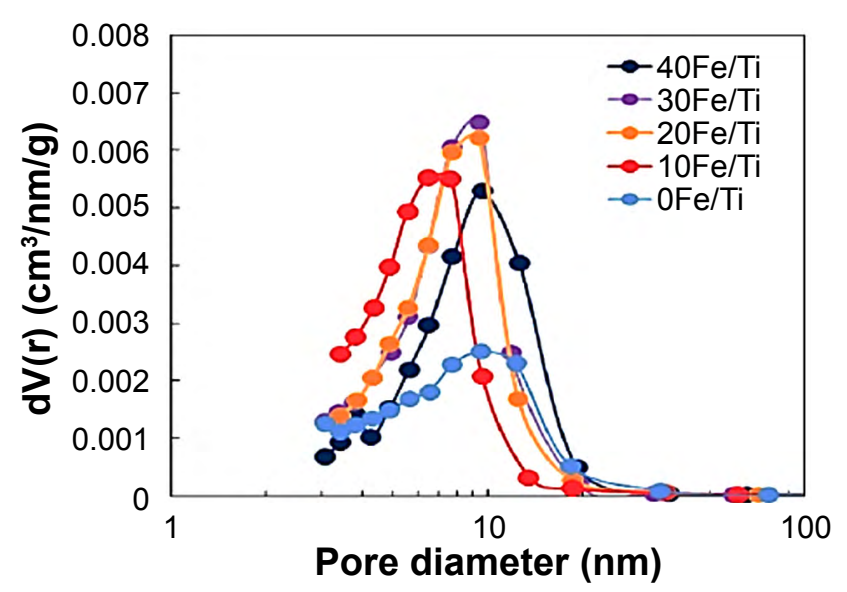

Figure 4: Pore size distribution curves of the prepared samples using BJH method.

[Figura 4: Curvas de distribuição de tamanho dos poros pelo método BJH das amostras preparadas.]

Dependence of magnetization on the applied magnetic field at room temperature of various $\mathrm{Fe} / \mathrm{Ti}$ composites is illustrated in Fig. 5. Pure titania $(0 \mathrm{Fe} / \mathrm{Ti})$ exhibited diamagnetic behavior. However, after iron dispersion in $\mathrm{TiO}_{2}$ structure, the magnetic properties of composite changed to ferromagnetic properties. The magnetic hysteresis loops of dispersed Fe/Ti showed the soft magnetic properties. The values of saturation magnetization (Ms) versus iron oxide content in composites is shown in Fig. 6 . The saturation magnetization increased exponentially with the increase of iron oxide content in composites due to the formation of magnetic phase on composites. The saturation magnetization value was $0.1,0.22,0.38$ 
and $0.82 \mathrm{emu} / \mathrm{g}$ for $10 \mathrm{Fe} / \mathrm{Ti}, 20 \mathrm{Fe} / \mathrm{Ti}, 30 \mathrm{Fe} / \mathrm{Ti}$ and $40 \mathrm{Fe} /$ $\mathrm{Ti}$, respectively. There are three phases of iron oxide such as magnetite $\left(\mathrm{Fe}_{3} \mathrm{O}_{4}\right)$, maghemite $\left(\gamma-\mathrm{Fe}_{2} \mathrm{O}_{3}\right)$ and hematite $\left(\alpha-\mathrm{Fe}_{2} \mathrm{O}_{3}\right)$. Magnetite and maghemite are ferromagnetic and ferrimagnetic type with saturation magnetization value of 92-100 and 60-80 emu/g, respectively, while hematite is weakly ferromagnetic or antiferromagnetic [34]. The saturation magnetization value of composite was very low compared to iron oxide contained in the composites. This result indicated that mainly $\alpha-\mathrm{Fe}_{2} \mathrm{O}_{3}$ possibly formed in the composite with a small portion of $\mathrm{Fe}_{3} \mathrm{O}_{4}$, which may be responsible for this observation.

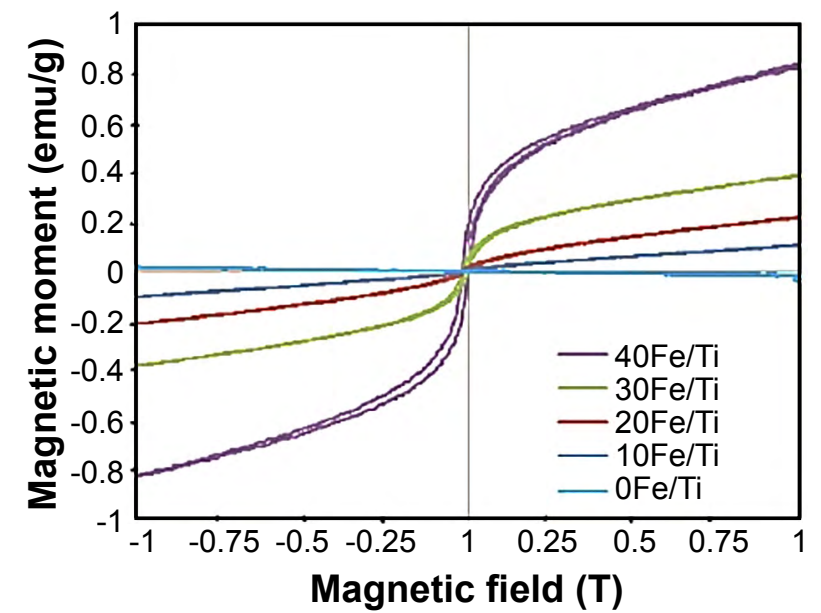

Figure 5: Magnetic hysteresis loops for various Fe/Ti composites. [Figura 5: Ciclos de histerese magnética para vários compósitos de Fe/Ti.]

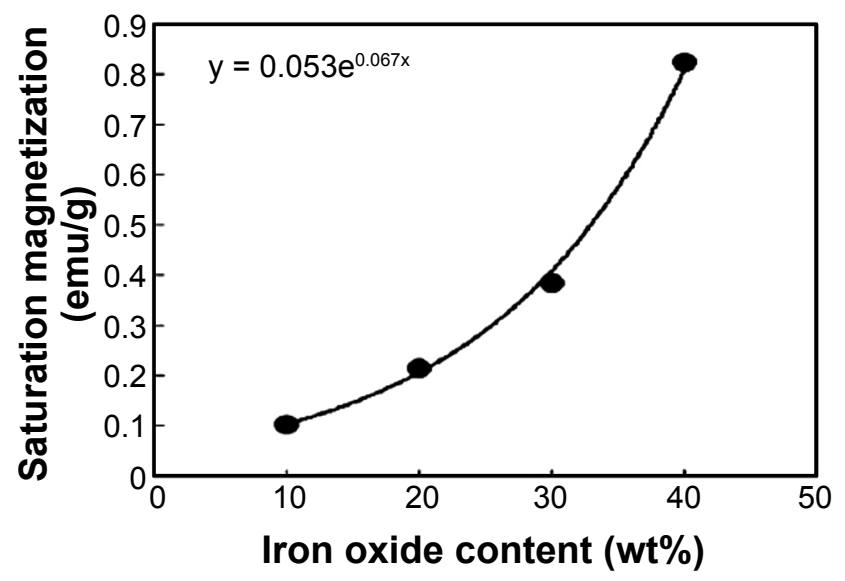

Figure 6: Saturation magnetization versus $\mathrm{Fe}$ content for $\mathrm{Fe} / \mathrm{Ti}$ composites.

[Figura 6: Saturação da magnetização versus teor de Fe nos compósitos Fe/Ti.]

Electromagnetic constitutive parameters of various $\mathrm{Fe} /$ Ti samples were calculated from the measured s-parameters (S11 and S21) using the Nicolson-Ross-Weir technique. The free-space reflection loss (RL) of the conductor-backed samples was calculated from the following equation:

$$
R L(d B)=20 \log \left|\frac{Z_{\text {in }}-Z_{0}}{Z_{\text {in }}+Z_{0}}\right|
$$

where the characteristic or intrinsic impedance of absorber $\left(\mathrm{Z}_{\text {in }}\right)$ is:

$$
Z_{\text {in }}=Z_{0} \sqrt{\frac{\mu_{\mathrm{r}}}{\varepsilon_{\mathrm{r}}}} \tanh \left[\left(-\mathrm{j} \frac{2 \pi}{\mathrm{c}}\right) \mathrm{fd} \sqrt{\mu_{\mathrm{r}} \varepsilon_{\mathrm{r}}}\right]
$$

where $\mu_{\mathrm{r}}$ and $\varepsilon_{\mathrm{r}}$ are the measured relative complex permeability and permittivity, respectively, $\mathrm{c}$ is the speed of light, $\mathrm{f}$ is the frequency of operation, and $\mathrm{d}$ is the thickness of the sample [35]. Fig. 7 shows the measured values of reflection loss of various $\mathrm{Fe} / \mathrm{Ti}$ composites in the frequency range $8-12 \mathrm{GHz}$ on $1 \mathrm{~mm}$ thick sample. The dips in the values of RL versus frequency imply low reflectivity (and good absorption). A broad absorption band with RL values of less than $-5 \mathrm{~dB}$ for all samples was obtained in 9.5$11.5 \mathrm{GHz}$ range of frequency which absorbed $50 \%$ of the electromagnetic wave. There was no significant difference of RL minimum value among $0 \mathrm{Fe} / \mathrm{Ti}, 10 \mathrm{Fe} / \mathrm{Ti}$ and $20 \mathrm{Fe} / \mathrm{Ti}$. Previously, the result of analysis of the XRD and Raman spectra showed that these three samples possessed a pure anatase phase. However, it was distinct concerning both $30 \mathrm{Fe} /$ $\mathrm{Ti}$ and $40 \mathrm{FeTi}$. It was observed that minimum reflection loss became deeper with the increased weight percent loading of $\mathrm{Fe}$ in the composite. The reflection loss value was founded $-12.6 \mathrm{~dB}$ and $-14.0 \mathrm{~dB}$ for $30 \mathrm{Fe} / \mathrm{Ti}$ and $40 \mathrm{Fe} / \mathrm{Ti}$, respectively, which absorbed over $80 \%$ of the electromagnetic wave. The decreasing of RL value was due to the presence of iron oxide in the composite, as explained in the analysis of XRD and Raman spectra before.

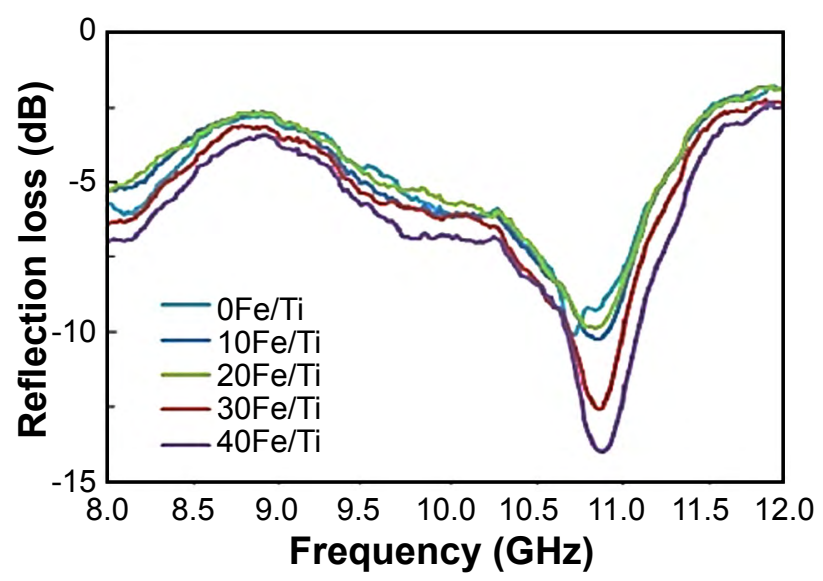

Figure 7: Reflection loss spectra of various Fe/Ti composites. [Figura 7: Espectros de perda de reflexão de vários compósitos de Fe/Ti.]

\section{CONCLUSIONS}

Iron oxide/titania composite with different weight fraction of iron oxide was successfully synthesized. The samples containing $0-20 \%$ of iron oxide were single-phase (anatase); composites containing three phases (anatase, hematite, and magnetite) were formed for $30-40 \%$ of iron oxide additions in the titania matrix. Crystallite size of anatase decreased from 10.3 to $9 \mathrm{~nm}$ with the increase of iron oxide content in 
titania. The all prepared samples showed the characteristics of mesoporous material. The magnetite properties of composites had ferromagnetic behavior. The presence of magnetic material in a dielectric material can increase the absorption efficiency of electromagnetic waves. We found that $40 \mathrm{Fe} / \mathrm{Ti}$ had the best reflection loss value $(-14.0 \mathrm{~dB})$ which was able to absorb $80 \%$ of the electromagnetic wave at $10.9 \mathrm{GHz}$.

\section{ACKNOWLEDGMENT}

This research was supported by Research and Development of Smart Magnetic program of DIPA Grants at Center for Science and Technology of Advanced Materials - National Nuclear Energy Agency, Republic of Indonesia.

\section{REFERENCES}

[1] Y. Wang, T. Li, L. Zhao, Z. Hu, Y. Gu, Energy Power Eng. 3 (2011) 580.

[2] F. Qin, C. Brosseau, J. Appl. Phys. 111 (2012) 61301.

[3] I. Hajimiri, M.S. Seyed Dorraji, M.H. Rasoulifard, A.R. Amani-Ghadim, M.R. Khoshroo, Mater. Sci. Eng. B SolidState Mater. Adv. Technol. 225 (2017) 75.

[4] A. Kumar, V. Agarwala, D. Singh, Adv. Powder Technol. 25 (2014) 483.

[5] P.T. Tho, C.T.A. Xuan, D.M. Quang, T.N. Bach, T.D. Thanh, N.T.H. Le, D.H. Manh, N.X. Phuc, D.N.H. Nam, Mater. Sci. Eng. B 186 (2014) 101.

[6] P.K. Singh, S. Mukherjee, C.K. Ghosh, S. Maitra, Cerâmica 63, 368 (2017) 549.

[7] A. Wypych, I. Bobowska, M. Tracz, A. Opasinska, S. Kadlubowski, A. Krzywania-Kaliszewska, J. Grobelny, P. Wojciechowski, J. Nanomater. 2014 (2014) 124814.

[8] V.L. Soethe, E.L. Nohara, L.C. Fontana, M.C. Rezende, J. Aerosp. Technol. Manag. 3, 3 (2011) 279.

[9] C.M. Choi, K.S. Ko, J. Navig. Port Res. Inter. Ed. 34, 2 (2010) 111.

[10] E.G. Paulo, M.S. Pinho, R.C. Lima, M.L. Gregoru, T. Ogasawara, Cerâmica 50, 314 (2004) 161.

[11] S. Ni, S. Lin, Q. Pan, F. Yang, K. Huang, D. He, J. Phys. D Appl. Phys. 42, 5 (2009) 55004.

[12] P. Saville, "Review of radar absorbing materials", Defence R\&D, Canada (2005).

[13] P.F. Guan, X.F. Zhang, J.J. Guo, Appl. Phys. Lett. 101
(2012) 153108.

[14] C.L. Zhu, M.L. Zhang, Y.J. Qiao, G.X. Xiao, F. Zhang, Y.J. Chen, J. Phys. Chem. C 114 (2010) 16229.

[15] J. Cao, W. Fu, H. Yang, Q. Yu, Y. Zhang, S. Wang, H. Zhao, Y. Sui, X. Zhao, Y. Leng, H. Zhao, H. Chen, X. Qi, Mater. Sci. Eng. 175, 1 (2010) 56.

[16] N.C. Poh, "Calculation of microwave permeability, permittivity and absorption properties of magnetic particle composites", Diss., Nat. Un. Singapore (2010).

[17] J. Zou, Z. Wang, M. Yan, H. Bi, J. Phys. D Appl. Phys. 47, 27 (2014) 275001.

[18] A. Fisli, D.S. Winatapura, W.A. Adi, Y. Taryana, J. Sains Mater. Indones. 20, 2 (2019).

[19] S. Sagadevan, Mater. Sci. Eng. 4, 3 (2015) 1.

[20] M. Khairy, W. Zakaria, Egypt. J. Pet. 23 (2014) 419.

[21] H.C. Choi, Y.M. Jung, S.B. Kim, Vib. Spectrosc. 37, 1 (2005) 33.

[22] F.D. Hardcastle, J. Ark. Acad. Sci. 65 (2011) 43.

[23] M. Scepanovic, S. Askrabic, V. Berec, A. Golubovic, Z. Dohcevic-Mitrovic, A. Kremenovic, Z.V. Popovic, Acta Phys. Pol. 115 (2009) 4.

[24] C. Lejon, L. Osterlund, J. Raman Spectrosc. 42, 11 (2011) 2026.

[25] A. Fisli, R. Saridewi, S.H. Dewi, J. Gunlazuardi, Adv. Mater. Res. 626 (2013) 131.

[26] K.A. Cychosz, R. Guillet-Nicolas, J. García-Martínez, M. Thommes, Chem. Soc. Rev. 46, 2 (2017) 389.

[27] O. Sheikhnejad-Bishe, F. Zhao, A. Rajabtabar-Darvishi, E. Khodadad, Int. J. Electrochem. Sci. 9 (2014) 4230.

[28] M. Thommes, K. Kaneko, A.V. Neimark, J.P. Olivier, F. Rodriguez-Reinoso, J. Rouquerol, K.S.W. Sing, Pure Appl. Chem. 87, 9-10 (2015) 1051.

[29] S.M.Abdel-Azim,A.K.Aboul-Gheit, S.M.Ahmed,D.S. El-Desouki, M.S.A. Abdel-Mottaleb, Int. J. Photoenergy 2014 (2014) 687597.

[30] M. Thommes, K.A. Cychosz, Adsorption 20, 2-3 (2014) 233.

[31] A.G. Khokhlov, R.R. Valiullin, M.A. Stepovich, J. Kärger, Colloid J. 70, 4 (2008) 507.

[32] K.S.W. Sing, Pure Appl. Chem. 57, 4 (1985) 603.

[33] K. Kaneko, J. Membr. Sci. 96, 94 (1994) 59.

[34] A.S. Teja, P.Y. Koh, Prog. Cryst. Growth Charact. Mater. 55, 1-2 (2009) 22.

[35] A. Teber, I. Unver, H. Kavas, B. Aktas, R. Bansal, J. Magn. Magn. Mater. 406 (2016) 228.

(Rec. 28/01/2019, Rev. 25/03/2019, Ac. 25/03/2019) 